\title{
Zbigniew Palmowski
}

Politechnika Wrocławska

e-mail: zbigniew.palmowski@gmail.com

\section{A NOTE ON VAR FOR THE WINNER'S CURSE* WARTOŚĆ ZAGROŻONA I PRZEKLEŃSTWO ZWYCIĘZCY}

\author{
DOI: $10.15611 / \mathrm{e} 21.2017 .3 .08$ \\ JEL Classification: C22, D44, G30
}

\begin{abstract}
Summay: This paper is an introduction to the concept and methodology of Value at Risk as a new tool for measuring exposure to the so-called winner's curse risk. This expression was first used in the work of [Capen, Clapp, Campbell 1971] related to the oil companies, and it is usually introduced by the elementary example of the auctioning of a sealed jar with coins. The bidders cannot exactly know the value of the jar, they can just estimate it by looking at it from a distance. Usually the winner is the bidder who overestimates the value of jar the most, but actually he/she loses because of paying more than he/she receives in the jar. The same happens in insurance aggregators, but here the lowest price wins (we have then the socalled reversed auction). Traditionally, insurance companies have tried to offer insurance prices at the level of the expected value of the future costs (including all operational costs and expected profit) but now the winning company very likely is not getting enough premium to cover the assumed risk. In the case bankrupcy, this compnay will have to then face so-called winner's curse. In this paper we analyse a few numerical examples.
\end{abstract}

Keywords: Winner's curse, Value at Risk, order statistics.

Streszczenie: W pracy autor stara się odpowiedzieć na pytanie, jak użyć konceptu wartości zagrożonej w szacowaniu ryzyka związanego z tzw. przekleństwem zwycięzcy. Podano też kilka statystycznych przykładów. Ostatnio firmy ubezpieczeniowe muszą stawić czoła dużo bardziej zaostrzonej konkurencji niż w przeszłości. Dodatkowo w ostatniej dekadzie ryzyko szkody na produktach ubezpieczeniowych nabiera nowego wymiaru ze względu na wprowadzenie tzw. porównywarek ubezpieczeniowych, tj. stron internetowych dających łatwą i szybką możliwość porównania cen szerokiej gamy produktów. Za każdym razem, gdy firmy sprzedają nową ochronę ubezpieczeniową, mogą mieć do czynienia ze zjawiskiem nazywanym przekleństwem zwycięzcy. Pojawia się ono wtedy, kiedy ubezpieczyciel ze względu na konkurencję zaoferuje cenę niższą niż ta, która opiera się na oczekiwanej warto-

* This work is partially supported by the National Science Centre under the grant DEC2011/01/B/HS4/00982 (2012-2013). All the authors kindly acknowledge the partial support by the project RARE-318984, a Marie Curie IRSES Fellowship within the 7th European Community Framework Programme. 
ści przyszłych kosztów. W dłuższym horyzoncie czasowym może to prowadzić do niewypłacalności. Dlatego ten problem wydaje się tak istotny.

Slowa kluczowe: ruina, przekleństwo zwycięzcy, licytacja, estymator.

\section{Introduction}

The problem of the ruin of an insurance company is very different from bankruptcy in most other types of businesses. This is a consequence of the specificity of the insurance business, which is in fact the selling of promises. Here, the production costs are very uncertain: whether they occur at all, when they occur and of what value. In the last decade, the risk of loss in insurance products has gained new dimension as a result of the introduction of so-called insurance aggregators, i.e. internet services allowing the easy, immediate and very wide comparison of prices (and terms and conditions) of insurance products. Some UK and US aggregators include offers from more than 100 companies. This situation mainly concerns potential purchasers of motor or household insurance. Therefore the companies are now facing much heavier price competition than ever before. Every time they sell new insurance cover, they deal with the phenomenon known as 'the winner's curse'. This expression was first used in the work of [Capen, Clapp, Campbell 1971] related to the oil companies, and it is usually introduced by the elementary example of the auctioning of a sealed jar with coins (see [Bazerman, Samuelson 1983]). The bidders cannot exactly know the value of the jar, they can just estimate it by looking at it from a distance. Usually the winner is the bidder who overestimates the value of jar the most, but actually he/she loses because of paying more than he/she receives in the jar. In very easy numerical examples it can be shown that if the mean of their estimators is equal to the real value of the jar, it is unlikely that the winner really wins. The size of the loss is strongly connected with the quality (for example standard deviation) of the estimators. The same happens in insurance aggregators, but here the lowest price wins (we have then the so-called reversed auction). Traditionally, insurance companies have tried to offer insurance prices at the level of the expected value of the future costs (including all operational costs and expected profit) but now the winning company very likely is not getting enough premium to cover the assumed risk. In fact, this insurance company can compensate the loss by selling other insurance and financial products which very often are not offered in insurance aggregators. To do this efficiently this insurance company needs to estimate the size of the risk related with selling the product sold on the aggregator, which is the main goal of this paper. Estimating the size of the loss is also important for another reason. The fact that the insurer has won the business will mean it is more likely that the insurer has underestimated the true costs of the claims. To make things even worse, a company making a significant error in its pricing can very quickly pick up large volumes of unprofitable and undesirable business. 
Most of the papers concern the auction market; see e.g. [Anandalingam, Luca 2004; Klemperer 2004] and [Pinker, Seidman, Vakrat 2003] for general considerations, [Dessaur 1981] for the publication rights, [Blecherman, Camerer 1998] and [Cassing, Douglas 1980] for sport agencies competition, [Roll 1986] for corporation overtaking, [Ashenfelter, Genesore 1992] for real estate auctions. A similar problem is also appearing in, for example, buying the rights to broadcast some sport events, on the electrical market or on the agricultural exchange.

There are only several models which study this phenomenon in actuarial context; see e.g. [Rothwell, Fulcher 2010; Svendgoard 2004] for an overview, [Shaffer 1998] for the bank loan market, [Harrington, Danzon 1994] for the property/liability insurance market and [Tu 2010] for the life insurance settlement market. Probably this phenomenon is caused by the fact that insurance aggregators have emerged in recent years. Previously the time and effort involved in seeking alternative quotes meant that many individuals would renew with existing providers if the provider had a trusted brand. Today, the ubiquity of aggregator sites advertising and the ease of access to a huge range of quotes means that behaviour is changing and most policyholders are tempted to check the competitiveness of their renewal quotes every year. As a result, even insurers who seek to avoid exposure to aggregator sites are effectively exposed to an auction, as they may only win the business if they effectively underbid the all the companies on the aggregator. Therefore incorporating the winner's curse in a valuation process is crucial. This is particularly important for insurance products with a long-term reporting period (such as third party liability where the report of the loss can be made even after thirty years). The General Insurance Research Organization treated this problem so seriously that it set up a special group of actuaries to examine this topic and prepare a comprehensive report.

In this paper to estimate the potential loss coming from the winner's curse, we propose the generalized Cox-Hayne model (see [Cox, Hayne 2005]) model assuming that some given insurance product has some common value $v$ for all insurance companies that offer this product which could be estimated based on the experience of insurers and known actuarial procedures. $v$ covers also all costs related to some insurance policies (jointly with all operational costs). Since the insurance company can also see the outcome of searching on an insurance aggregator for some typical input data, theoretically it could suggest only a slightly lower price than other companies offering the given product. This strategy would be the best one if we assume that all conditions of the insurance policy are very similar for each insurance company and that the consumer will choose the offer with a lower price. To avoid this "reading" strategy, insurance companies usually add some randomness to $v$. This can be easily noted for example in car insurance policies. Entering the given data of driver and car twice within a short period of time usually produces two different prices. To simplify the calculations, we assume that each company uses the same random mechanism which is modeled by the independent random variable with mean $v$. 
For this model we analyse the Value at Risk measure which estimates the potential loss for a given $1-\alpha$ confidence interval. In the last decade, VaR has becomes the established measure of risk exposure in financial service firms and has begun to find acceptance in non-financial service firms. The impetus for the use of VaR measures came from the crises that beset financial service firms over time and the regulatory responses to these crises. Solvency Capital Requirement (SCR) cappearing in Solvency II is also based on a VaR measure calibrated to a 0.995 confidence level over a one-year time horizon. The SCR covers all risks that an insurer faces (e.g. insurance, market, credit and operational risk) and takes full account of any risk mitigation techniques applied by the insurer (e.g. reinsurance and securitisation). Therefore it seems that this is the most natural measure of calculating the possible loss in the scenario that we deal with in this paper.

The paper is organized as follows. In the next Section we describe our model in detail and present the main results. In Section 3 we analyse a few numerical examples. Section 4 comments on the main results.

\section{Main results}

Assume that the true common value of the offered insurance product equals $v$ (taking into account all costs). We have $N \in\{1,2, \ldots\}$ insurers. $i$ th insurance company offers the price $X_{i}, i=1,2, \ldots, N$ according to a sequence of i.i.d. random variables $\left\{X_{i}\right\}$ with mean $v$. Let $F$ denote the distribution function of generic $X$ and $f$ its density function (we assume that it exists). We assume also that the consumer will always choose the cheapest offer, which means that either the offered policy conditions are similar or the price is the dominant feature for the making decision. This assumption seems to be particularly natural in countries where the prices of insurance contracts are high. Hence the consumer will pay $X_{1: N}=\min \left\{X_{1}, X_{2}, \ldots, X_{N}\right\}$ which is a first order statistics of the sample $\left(X_{1}, \ldots, X_{N}\right)$. Note that:

$$
\mathrm{P}\left(X_{1: N} \leq x\right)=1-(1-F(x))^{N} .
$$

Hence the loss $-L$ of the winner (which is the insurance company offering the best price for given insurance product) equals:

$$
L=v-X_{1: N} .
$$

Note that formally here still $L$ could have positive values. Still the average loss $-\mathrm{E} L$ could be negative since it equals:

$$
\left.\mathrm{E} L=v-N \int_{0}^{\infty} x\left(1-F(x)^{N-1}\right) f(x) \mathrm{d} x=\int_{0}^{\infty} x\left[1-N(1-F(x))^{N-1}\right)\right] f(x) \mathrm{d} x .
$$


Therefore we will use the term 'loss' in all the scenarios to describe the heuristics of $L$. Thus on average the winning insurance company is losing on this offer. To see how much it loses on a single contract, let us consider the random mechanism that insurance companies apply based on uniform distribution. That is, for given $\theta>0$ let $X_{i}: \mathrm{U}[v-\theta, v+\theta], i=1, \ldots, N$. In this case,

$$
\mathrm{E} L=\theta \frac{N-1}{N+1} .
$$

Indeed, for this distribution of generic $X$ we have that

$$
Y=\frac{1}{2}\left(\frac{X-v}{\theta}+1\right)
$$

has uniform distribution on interval $[0,1]$. Then denoting $Y_{1: N}=\min \left\{Y_{1}, \ldots, Y_{N}\right\}$ we have

$$
X_{1: N}=2 \theta Y_{1: N}+v=\theta,
$$

which gives (4) since $\mathrm{E} Y_{1: N}=1 / N$. Note that the average loss in this case does not increase even for a large number of competing insurance companies:

$$
\lim _{N \rightarrow \infty} \mathrm{E} L=\theta .
$$

In fact in this case we can derive a more explicit distribution of loss $L$. Indeed, since $Y_{1: N}$ has $\operatorname{Beta}(1, N)$ distribution we have:

$$
\mathrm{P}(L \leq x)=\frac{1}{\operatorname{Beta}(1, N)} \int_{\left(1-\frac{x}{\theta}\right) / 2}^{\infty}(1-t)^{N-1} \mathrm{~d} t=\frac{1}{2}\left(1+\frac{x}{\theta}\right) .
$$

In general to estimate the possible loss by the winning company we will consider Winner's Value at Risk (abbreviated to WVaR). For given $\alpha \in(0,1)$ we will look for $z=\mathrm{WVaR}$ such that

$$
\mathrm{P}(L>z)=\alpha .
$$

In other words, the winning insurance company can accept a loss of size $z$ only with a very small probability, say with probability $\alpha=0.95$ hoping that it can cover the loss from the other insurance products sold to the given client. Otherwise this value is too large for the insurance company and it should refrain from giving a very low price for that type product and consumer. Dividing possible consumers into homogeneous groups will simplify the above procedure and can give a reasonable strategy of offering the insurance products. 
The main result of this paper is the identification of WVaR for this type of problem.

Theorem 1. We have

$$
\mathrm{W} \operatorname{VaR}=v-F^{-1}(1-\sqrt{1-\alpha}),
$$

where $F^{-1}$ is the generalized inverse of $F$.

Proof. From (1) we have the identity

$$
1-(1-F(v-z))^{N}=\alpha
$$

which produces the assertion of the theorem.

From the above theorem or directly from (6) we can get the following corollary.

Corollary 2. If the offered prices $X_{i}, i=1, \ldots, N$ have uniform distribution $U[v-\theta, v+\theta]$, then

$$
\mathrm{W} \operatorname{VaR}=\theta(2 \sqrt[N]{1-\alpha}-1)
$$

\section{Numerical examples}

In this section we present a few numerical examples which show the influence of choice of the random mechanism and its parameters on the possible loss.

We start from showing in Table 1 the mean loss size $\theta \frac{N-1}{N+1}$ found in equation (4) when the offers have uniform distribution $\mathrm{U}[v-\theta, v+\theta]$ around true value $v$.

Table 1. Mean loss for the uniform offers

\begin{tabular}{|c|c|c|c|c|}
\hline$\theta N$ & 5 & 10 & 50 & 100 \\
\hline 0,1 & 0.067 & 0.082 & 0.096 & 0.098 \\
\hline 0,3 & 0.200 & 0.245 & 0.288 & 0.294 \\
\hline 0,5 & 0.333 & 0.409 & 0.480 & 0.490 \\
\hline
\end{tabular}

Source: own work.

In Figures 1 and 2 we show the dependence of loss on parameter $\theta$ and the number of insurance companies giving the offer, on $N$, respectively.

In Table 2 we calculate WVaR for $N=5$ insurance companies and when the offers have uniform distribution $\mathrm{U}[v-\theta, v+\theta]$.

In Figures 3 and 4 we present the dependence of WVaR on parameter $\theta$ and $\alpha$. 


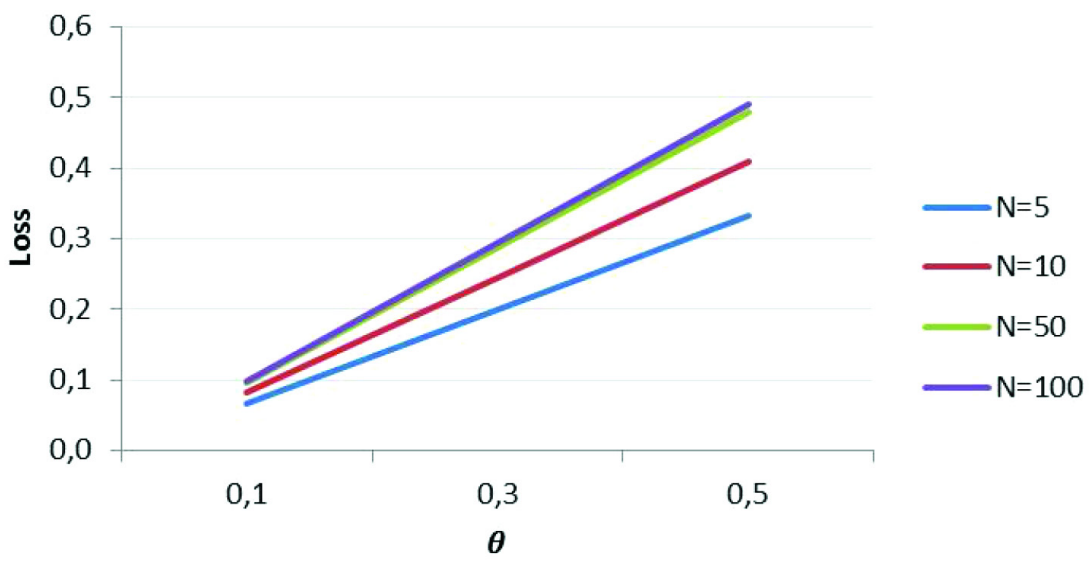

Fig. 1. Dependence of mean loss on $\theta$

Source: own work.

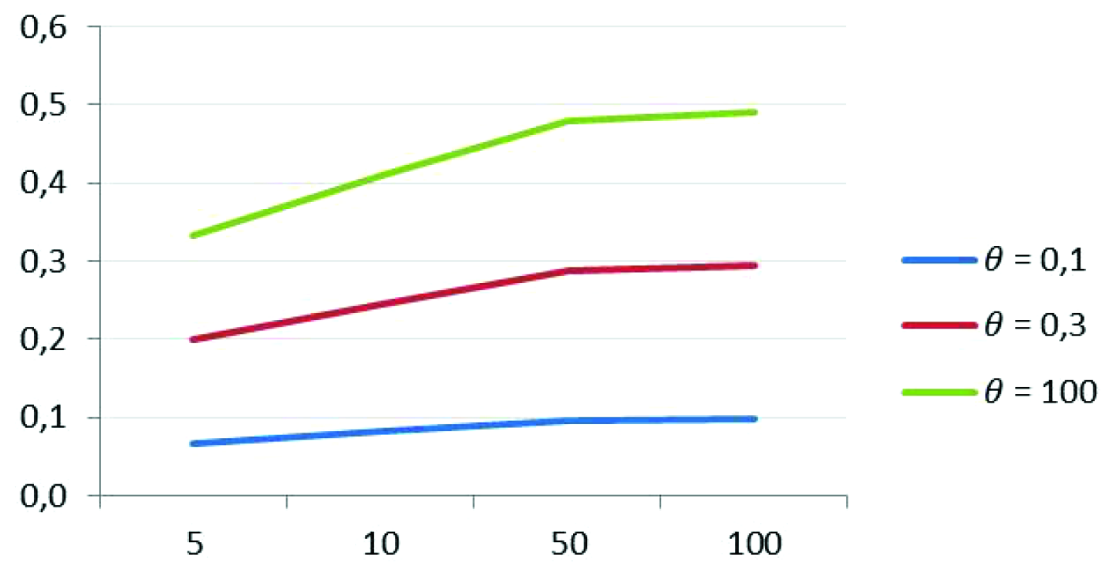

Fig. 2. Dependence of mean loss on the number of offers $N$

Source: own work.

Table 2. WVaR for $N=5$ and uniform offers

\begin{tabular}{|c|c|c|c|c|}
\hline$\theta / \alpha$ & 0.01 & 0.05 & 0.1 & 0.3 \\
\hline 0.1 & 0.100 & 0.098 & 0.096 & 0.086 \\
\hline 0.3 & 0.299 & 0.294 & 0.287 & 0.259 \\
\hline 0.5 & 0.498 & 0.490 & 0.479 & 0.431 \\
\hline
\end{tabular}

Source: own work. 


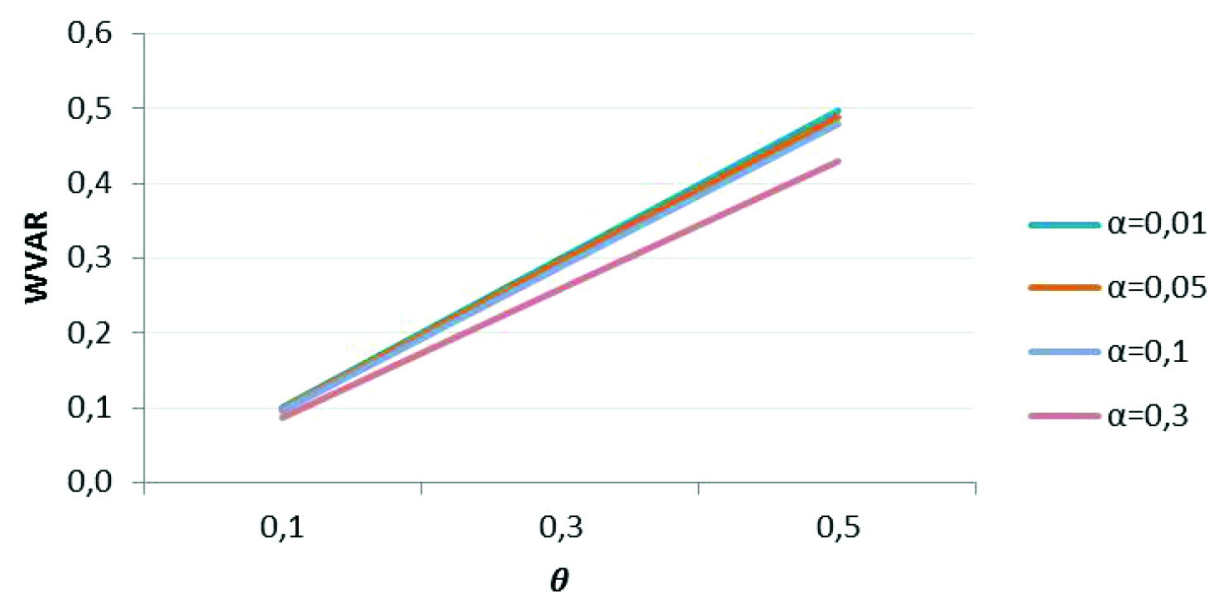

Fig. 3. Dependence of $\mathrm{WVaR}$ on $\theta, N=5$

Source: own work.

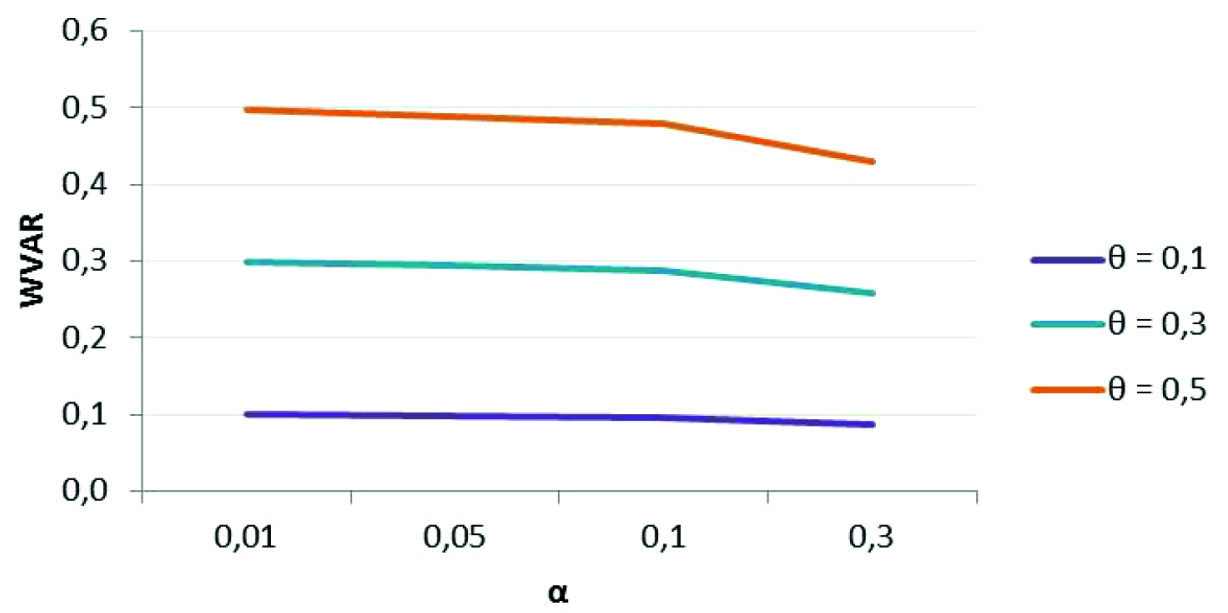

Fig. 4. Dependence of $\mathrm{WVaR}$ on $\alpha, N=5$

Source: own work.

We also made the above calculation for a larger number of insurance companies $N=10$ (see Table 3 and Figures 5 and 6). As one can see, the change is not substantial which is surprising.

Finally, we did the same numerical analysis for the exponential distribution of offers with parameter $\lambda$ assuming that we have $N=5$ insurance companies competing with each other (see Table 4) and for a Gaussian distribution with 
Table 3. WVaR for $N=10$ and the uniform offers

\begin{tabular}{|c|c|c|c|c|}
\hline$\theta / \alpha$ & 0.01 & 0.05 & 0.1 & 0.3 \\
\hline 0.1 & 0.100 & 0.099 & 0.098 & 0.093 \\
\hline 0.3 & 0.299 & 0.297 & 0.294 & 0.279 \\
\hline 0.5 & 0.499 & 0.495 & 0.490 & 0.465 \\
\hline
\end{tabular}

Source: own work.

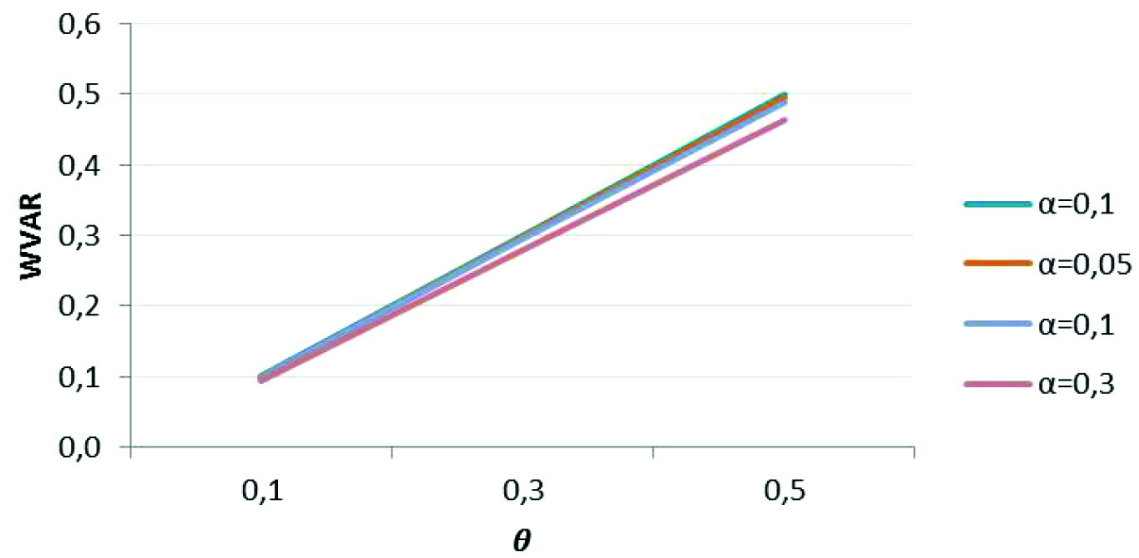

Fig. 5. Dependence of WVaR on $\theta, N=10$

Source: own work.

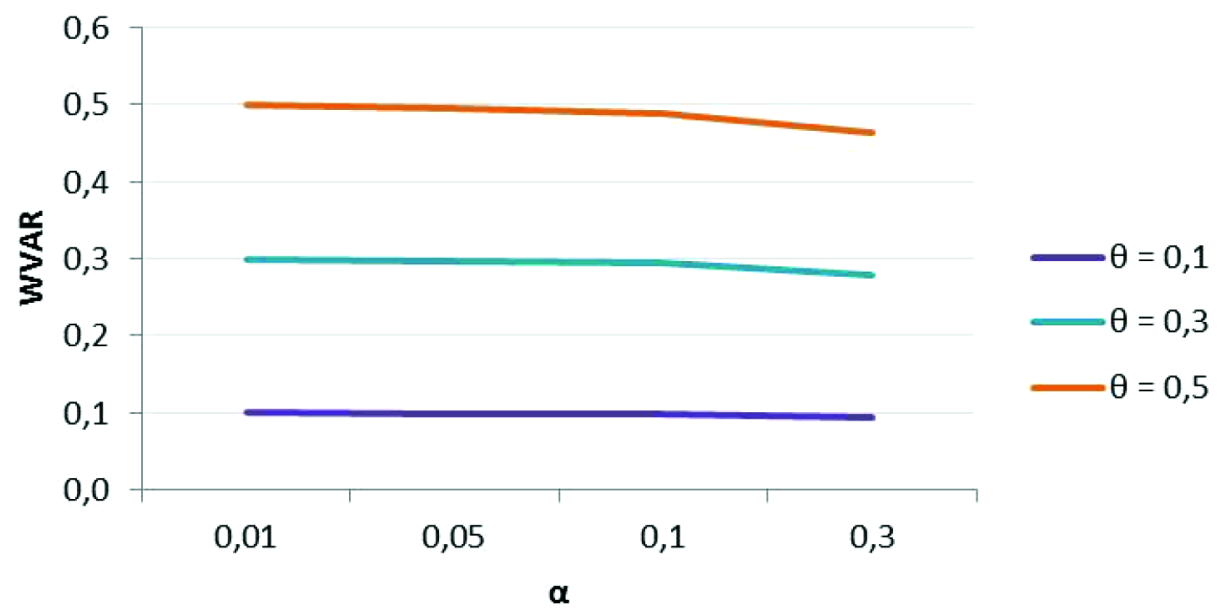

Fig. 6. Dependence of $\mathrm{WVaR}$ on $\alpha, N=10$

Source: own work. 
Table 4. WVaR for exponentially distributed offers

\begin{tabular}{|c|c|c|c|c|}
\hline$\lambda \backslash \alpha$ & 0.01 & 0.05 & 0.1 & 0.3 \\
\hline 0.01 & 199.80 & 198.98 & 197.91 & 193.11 \\
\hline 0.03 & 66.60 & 66.33 & 65.97 & 64.37 \\
\hline 0.05 & 39.96 & 39.80 & 39.58 & 38.62 \\
\hline
\end{tabular}

Source: own work.

Table 5. WVaR for Gaussian offers with $\sigma=0,2$

\begin{tabular}{|c|c|c|c|c|}
\hline$M \alpha$ & 0.01 & 0.05 & 0.1 & 0.3 \\
\hline 5 & 0.58 & 0.46 & 0.41 & 0.30 \\
\hline 10 & 0.62 & 0.51 & 0.46 & 0.36 \\
\hline 50 & 0.71 & 0.62 & 0.57 & 0.49 \\
\hline
\end{tabular}

Source: own work.

volatility $\sigma=0,2$ (see Table 5). One can observe that the loss in exponentials case is substantially larger. This means that the appropriate choice of distribution of offers chosen by insurance companies could be crucial for the sizes of their losses. Moreover, in the case when the offers have Gaussian distribution centered around the true value of the insurance product, the values of WVaR are similar to the one with uniform offers.

\section{Conclusions}

This paper analyses the winner's curse phenomenon in the insurance business. The importance of the problem is caused mainly by the ubiquity of aggregator sites advertising insurance products, mainly car and household polices. This sites change the behaviour of policyholders who can easily compare the prices and are tempted to choose the cheapest offer. The insurance company knows it may only win the business if it effectively underbids all the other companies. Of course, insurance companies amassing more consumers can offer them other properly priced insurance products compensating them for the loss. Still, if the loss is too large the winning insurance company will suffer from the winner's curse, mainly due to obtaining a large number of clients thanks to the aggressive market strategy. Therefore incorporating the winner's curse in a valuation process is very crucial.

In fact, to price properly the offered products on aggregators, the insurance company has to effectively estimate the possible loss. The most natural tool comes from calculating $\mathrm{VaR}$, which is given in Theorem 1. We consider here the model where companies estimate correctly the common value of a given product but intentionally add a random mechanism to that price. We also assumed that this mechanism is common for all insurance companies competing with each other. We analysed numerically the influence of the number of insurance companies and the 
distribution of the stochastic mechanism on the loss using VaR technology. We proved that the loss only very slightly depends on the number of insurance companies. Besides this, when choosing the uniform random mechanism of size $\theta$, the loss linearly depends on that size. Finally, we show that the choice of distribution of the given offers by insurance companies could be crucial for the possible loss.

\section{Bibliography}

Anandalingam G., Luca H.C., 2004, Beware the Winner's Curse: Victories that Can Sink You and Your Company, Oxford University Press.

Ashenfelter O., Genesore D., 1992, Testing for price anomalies in real estate auctions, American Economic Review: Papers and Proceedings, 82, pp. 501-505.

Bazerman M.H., Samuelson W.F., 1983, I won the auction but don't want the prize, Journal of Conflict Resolution, 27, pp. 618-634.

Blecherman B., Camerer C., 1998, Is There a Winner's Curse in the Market for Baseball Players?, Mimeograph, Brooklyn Polytechnic University, Brooklyn, N.Y.

Capen E., Clapp R., Campbell V., 1971, Competitive bidding in high-risk situations, Journal of Petroleum Technology, 23, pp. 641-653.

Cassing J., Douglas R.W., 1980, Implications of the auctions mechanism on baseball's free agent draft, Souther Economic Journal, 47, pp. 110-121.

Cox J.C., Hayne S.C., 2005, When does an incentive for free riding promote rational bidding?, Experimental Business Research, pp. 133-149.

Dessaur J.P., 1981, Book Publishing, Bowker, New York.

Harrington S., Danzon P., 1994, Cutting in liability insurance markets, Journal of Business, 67(4), pp. 511-538.

Klemperer P., 2004, Auctions: Theory and Practice, Princeton University Press.

Pinker E.J., Seidman A., Vakrat Y., 2003, Managing online auctions: current business and research issues, Management Science, 49(11), pp. 1457-1484.

Roll R., 1986, The Hubris hypothesis of corporate takeovers, Journal of Business, 59, pp. 197-216.

Rothwell M., Fulcher G., 2010, Winners 's curse giro working party, GIRO conference papers.

Shaffer S., 1998, The winner's curse in banking, Journal of Financial Intermediation, 7, pp. 359-392.

Svendgoard C., 2004, The winner's curse in reinsurance, American Academy of Actuaries Contingencies Magazine, www.contingencies.org/septoct04/curse.pdf.

Tu P., 2010, Winner's Curse and the Competitive Effect: Measuring Competition in the Viatical Settlement Market, MIMEO, Stanford University. 